\title{
PEMBERDAYAAN UMKM DAN LEMBAGA KEUANGAN SYARIAH MELALUI PRINSIP BAGI HASIL
}

\author{
Rizki Tri Anugrah Bhakti, Mochammad Bakri dan Siti Hamidah \\ Fakultas Hukum Universitas Brawijaya Malang \\ Email:hamidah@ub.ac.id
}

\begin{abstract}
Abstrak
This article describes the micro, small and medium enterprises (SMEs), which has high ability to absorb labor market, as many as $97.3 \%$ from the total labor force working. However, the role of micro, small and medium enterprises (SMEs) in the reality have difficulties in some factors, one of the factor is capital issues. This is where Syariah financial institution with the profit sharing principal to be expected become ideal solution, this because on the financing use the profit sharing principal. Observing phenomenon as above it is necessary to have assessment on few point area, first, implementation of financing on Syariah financial institution in the Malang City perceived become ideal solutions. Second, the factors which become the barrier on implementation of financing on Syariah financial institution in Malang City. Third; the right solution to overcome the barrier factors on the implementation at Shariah financial institution in Malang City concerning exact profit sharing principal.

Artikel ini membahas tentang kemampuan usaha mikro, kecil dan menengah (UMKM) dalam menyerap tenaga kerja di Indonesia yang cukup besar, yaitu sebanyak 97,3\% dari total angkatan kerja yang bekerja. ${ }^{1}$ Namun peran tersebut dalam kenyataannya terkendala oleh beberapa hal, diantaranya permasalahan modal. Disinilah peran Lembaga Keuangan Syari'ah dengan pembiayaan berprinsip bagi hasil sangat diharapkan. Mengamatifenomena yang demikian maka perlu dikaji mengenai beberapa hal; pertama, pelaksanaan pembiayaan pada Lembaga Keuangan Syari'ah di kota Malang yang dirasa ideal bagi usaha mikro, kecil dan menengah (UMKM). Kedua, faktor-faktor penghambat pelaksanaan pembiayaan pada Lembaga Keuangan Syari'ah di Kota Malang berkenaan dengan prinsip bagi hasil, dan ketiga, solusi untuk mengatasi faktor-faktor penghambat pelaksanaan pembiayaan pada Lembaga Keuangan Syari'ah di Kota Malang berkenaan dengan prinsip bagi hasil yang ideal tersebut.
\end{abstract}

Kata Kunci: UKM, Bagi hasil, Lembaga Keuangan Syari'ah.

${ }^{1}$ Bank Indonesia, "Buku Kajian Akademik Pemeringkat Kredit Bagi Usaha Mikro, Kecil dan Menengah di Indonesia”, (Jakarta: Bank Indonesia, 2011). www.bi.go.id. Diakses tanggal 08 Februari 2013. 
Kemampuan usaha mikro, kecil dan menengah (UMKM) dalam menyerap tenaga kerja di Indonesia cukup besar, yaitu sebanyak $97,3 \%$ dari total angkatan kerja yang bekerja. ${ }^{2}$ Data Badan Pusat Statistik (BPS) mencatat jumlah usaha mikro, kecil dan menengah (UMKM) di Indonesia tahun 2008 adalah lebih dari 51.000 .000 (lima puluh satu juta) unit, dan merupakan unit usaha terbesar dari total unit usaha yang ada. Ini menandakan bahwa usaha mikro, kecil dan menengah (UMKM) memiliki peran yang penting terutama dalam memperluas lapangan kerja, meningkatkan pendapatan masyarakat sehingga dapat menjadi penggerak pembangunan dan pertumbuhan ekonomi.

Partisipasi dari seluruh elemen negara sangat diperlukan, baik pemerintah, masyarakat, dunia usaha, serta lembaga keuangan dalam mewujudkan tujuan tersebut. Misalnya, pemerintah dengan kebijakan yang mendukung perkembangan usaha mikro, kecil dan menengah (UMKM), masyarakat yang menggunakan barang dan/atau jasa hasil usaha mikro, kecil dan menengah (UMKM) dalam memenuhi kebutuhan hidupnya, dunia usaha yang bisa berjalan sehat sehingga tidak terjadi kecurangan yang berakibat terpuruknya usaha mikro, kecil dan menengah (UMKM), serta lembaga keuangan yang dapat mendukung dan membantu mengatasi permasalahan permodalan yang merupakan permasalahan yang umum dihadapi oleh mereka. Keterbatasan modal akan menyebabkan ruang gerak usaha mikro, kecil dan menengah (UMKM) semakin sempit, ${ }^{3}$ misalnya mengalami kesulitan dalam mengembangkan usahanya dikarenakan tidak mampu memenuhi pesanan dari konsumen.

\footnotetext{
${ }^{2}$ Bank Indonesia, "Buku Kajian Akademik Pemeringkat Kredit Bagi Usaha Mikro, Kecil dan Menengah di Indonesia", (Jakarta: Bank Indonesia, 2011). www.bi.go.id. Diakses tanggal 08 Februari 2013.

${ }^{3}$ Artikel Suara Merdeka.com, "Bank Syariah dan Industri Kreatif", diakses tanggal 31 Desember 2012. Artikel Suara Merdeka.com, "Pertumbuhan Perbankan Syariah Belum Optimal", diakses tanggal 08 November 2012. Artikel Republica.co.id, "Pertumbuhan Perbankan Syariah Belum Optimal", diakses tanggal 27 Oktober 2011. Artikel Kompas. com "Keterbatasan UKM Dalam Meraih Pembiayaan Bank Syariah", diakses tanggal 03 Januari 2010.
}

Bila hal tersebut tidak teratasi maka dapat dimungkinkan usaha menciptakan lapangan pekerjaan akan kembali sulit diupayakan.

Lembaga Keuangan Syari'ah hadir sebagai wujud perkembangan aspirasi masyarakat yang menginginkan kegiatan perekonomian dengan berdasarkan prinsip syariah, selain lembaga keuangan konvensional yang telah berdiri selama ini. Lembaga Keuangan Syari'ah tersebut diantaranya adalah bank syariah dan Baitul Maal wat Tamwil (BMT) atau lembaga keuangan mikro syariah. Bila pada perbankan konvensional hanya terdapat satu prinsip yaitu bunga, maka pada Lembaga Keuangan Syari' ah terdapat pilihan prinsip yang dapat disesuaikan dengan kebutuhan nasabah, yaitu prinsip bagi hasil, prinsip jual beli, prinsip sewa, dan prinsip jasa. Salah satu prinsip yang tepat diperuntukkan bagi pemberdayaan usaha mikro, kecil dan menengah (UMKM) adalah prinsip bagi hasil. Secara umum prinsip bagi hasil dapat dilakukan dalam empat akad, yaitu mudharabah, musyarakah, muzara'ah, dan musaqah. Namun dalam praktiknya akad yang paling banyak dipakai adalah mudharabah dan musyarakah.

Pembiayaan dengan akad mudharabah dan musyarakah pada dasarnya merupakan pembiayaan yang sempurna, pada pembiayaan tersebut digunakan prinsip bagi hasil keuntungan (profit sharing). ${ }^{4}$ Selain menggunakan prinsip bagi hasil keuntungan (profit sharing), hal lain yang membuat ideal adalah adanya pembagian kerugian (loss sharing). Kerugian pada pembiayaan dengan akad mudharabah akan ditanggung sepenuhnya oleh bank, kecuali bila nasabah melakukan kelalaian dan kesengajaan yang menyebabkan dialaminya kerugian. Kerugian pada pembiayaan dengan akad musyarakah akan dihitung sesuai dengan porsi modal masing-masing pihak, yaitu pihak bank dan nasabah. Pada dasarnya dengan prinsip bagi kerugian (loss sharing) ini, maka kedua pihak yaitu pihak nasabah dan pihak bank akan berusaha untuk menghindari terjadinya kerugian tersebut. Mereka akan

\footnotetext{
${ }^{4}$ Burhanuddin S, Hukum Bisnis Syariah, (Yogyakarta: UII Press, 2011), h. 125.
} 
bekerja sama guna menghindari terjadinya kerugian usaha mereka, nasabah akan bekerja keras dalam mengembangkan usahanya, di sisi lain pihak bank memberikan pembinaan dan pengawasan dalam usaha tersebut.

Pada pembiayaan mudharabah bank bertindak sebagai shahibul maal yang menyediakan dana secara penuh dan nasabah bertindak sebagai mudharib yang mengelola dana dalam kegiatan usaha. Pembiayaan mudharabah ini memiliki karakter yang berbeda dengan kredit yang diberikan oleh bank konvensional, karakter tersebutadalah adanya keadilan dan kebersamaan yang merupakan semangat dari perbankan syariah. Hal ini dapat terlihat dari pembagian keuntungan dan kerugian di antara bank dengan nasabah pengelola dana. Keuntungan akan dibagi sesuai dengan kesepakatan yang tertuang dalam akad, sedangkan kerugian akan ditanggung oleh bank kecuali jika pihak nasabah pengelola dana melakukan kesalahan yang disengaja, lalai atau menyalahi perjanjian. Pada pembiayaan musyarakah maka terjadi percampuran dana antara dua pihak atau lebih untuk melakukan usaha tertentu yang halal dan produktif dengan kesepakatan bahwa keuntungan akan dibagi sesuai dengan nisbah yang disepakati dan risiko akan ditanggung sesuai porsi kerjasama.

Prosentase pemberian pembiayaan dengan prinsip bagi hasil, baik mudharabah maupun musyarakah dalam prakteknya masih lebih kecil bila dibandingkan dengan pembiayaan lain yang juga ditawarkan oleh perbankan syariah. Misalnya saja bila dibandingkan dengan pembiayaan murabahah yaitu pembiayaan dengan prinsip jual beli. Pada pembiayaan murabahah bank menyediakan dana atau tagihan untuk transaksi jual beli barang sebesar harga pokok ditambah margin atau keuntungan berdasarkan kesepakatan dengan nasabah.

Kecilnya porsi pembiayaan dengan prinsip bagi hasil muncul disebabkan karena beberapa persoalan, misalnya pembiayaan dengan prinsip bagi hasil sangat berisiko dan membutuhkan transparansi informasi juga kepercayaan tinggi antara pemilik modal (shahibul maal) dan pengelola usaha (mudharib), usaha mikro kecil sering dianggap sebagai unit usaha yang oleh perbankan sering disebut sebagai unit usaha yang tidak bankable, kebijakan perbankan itu sendiri, sehingga masyarakat berperilaku yang kurang menempatkan faktor kejujuran ketika mendapatkan pembiayaan dengan prinsip bagi hasil.

Kota Malang dengan penduduk yang bukan hanya dihuni oleh penduduk asli namun juga pendatang, memiliki potensi yang sangat baik terhadap perkembangan usaha mikro, kecil dan Menengah (UMKM). ${ }^{5}$ Tercatat untuk jenis usaha handycraft, fashion dan makanan yang potensial sebagai oleh-oleh, jumlah usaha mikro, kecil dan menengah (UMKM) adalah lebih kurang 63.000. Di sinilah Lembaga Keuangan Syari'ah diharapkan perannya mengingat perkembangan jumlah usaha mikro, kecil dan menengah (UMKM) di kota Malang kian hari akan semakin bertambah. Terlebih dengan adanya kebijakan perbankan, berkaitan dengan adanya Peraturan Bank Indonesia Nomor 14/22/PBI/2012 tentang Pemberian Kredit atau Pembiayaan Oleh Bank Umum dan Bantuan Teknis Dalam Rangka Pengembangan Usaha Mikro, Kecil dan Menengah. Pada Peraturan Bank Indonesia ini telah dengan jelas disebutkan bahwa bank umum termasuk bank syariah wajib memberikan kredit atau pembiayaan kepada usaha mikro, kecil dan menengah (UMKM) denganjumlah kredit atau pembiayaan ditetapkan paling rendah $20 \%$ (dua puluh persen) dari total kredit atau pembiayaan yang dilakukan, serta hadirnya undang-undang yang khusus menanungi lembaga keuangan mikro yaitu Undang-Undang Nomor 1 Tahun 2013 tentang Lembaga Keuangan Mikro, seperti halnya Baitul Maal wat Tamwil (BMT).

\section{METODE PENELITIAN}

Jenis penelitian yang digunakan disini adalah penelitian hukum empiris sebagaimana yang dikemukakan oleh Soerjono Soekanto, dengan pendekatan (approach) yang digunakan dalam penelitian ini adalah yuridis sosiologis.

\footnotetext{
${ }^{5}$ Data statistik Dinas Koperasi dan Usaha kecil dan Menengah Kota Malang Tahun 2011
} 
Secara yuridis memfokuskan pada prinsip kehati-hatian yang dilakukan oleh perbankan syariah dalam memberikan pembiayaan dengan prinsip bagi hasil kepada usaha mikro, kecil, dan menengah (UMKM), sedangkan sosiologis berfokus kepada ikut sertanya perbankan syariah dan Baitul Maal wat Tamwil (BMT) dalam memberdayakan usaha mikro, kecil dan menengah (UMKM) melalui pembiayaan dengan prinsip bagi hasil.

Jenis dan sumber data yang akan digunakan dan dianalisis dalam penelitian ini adalah data primer dan data sekunder. Data primer yaitu data yang diperoleh langsung, diamati, dan dicatat untuk pertama kalinya. ${ }^{6}$ antara lain penjelasan karyawan Lembaga Keuangan Syari'ah dan pemilik usaha mikro, kecil dan menengah (UMKM). Data ini juga ditunjang oleh penjelasan stakeholder yang terkait seperti Dinas Koperasi dan UKM. Penjelasan yang diberikan baik oleh sumber maupun stakeholder di atas berisi tentang persepsi mereka terhadap pemberdayaan yang dilakukan oleh Lembaga Keuangan Syari'ah kepada usaha mikro, kecil dan menengah (UMKM) melalui pembiayaan dengan prinsip bagi hasil.

Data sekunder yaitu mencakup dokumendokumen resmi, buku-buku, peraturan perundangundangan, dan bahan dari kepustakaan dengan mengumpulkan berbagai literatur serta data dokumen. ${ }^{7}$ Data ini digunakan untuk keperluan memperjelas data primer yang telah penulis dapatkan dari lapangan. Data ini bersumber dari Undang-Undang Nomor 7 Tahun 1992 sebagaimana telah diubah dengan UndangUndang Nomor 10 Tahun 1998 tentang Perbankan, Keputusan menteri Koperasi dan Usaha kecil dan Menengah Nomor:91/Kep/M. KUKM/IX/2004 tentang Petunjuk pelaksanaan Kegiatan Usaha Koperasi Jasa Keuangan Syariah, yang bertindak sebagai peraturan pelaksana sebelum adanya Undang-Undang Nomor 1 Tahun 2013 tentang Lembaga Keuangan Mikro, Undang-Undang Nomor 20 Tahun 2008 tentang

\footnotetext{
${ }^{6}$ Marzuki, Metodologi Riset, (Yogyakarta: BPFE UII, 1986), h. 56.

${ }^{7}$ Soerjono Soekanto dan Sri Mamudji, Penelitian Hukum Normatif: Suatu Tinjauan Singkat. (Jakarta: Raja Grafindo Persada, 2003), h. 11-13.
}

usaha mikro, kecil dan menengah, Al-Qur'an dan Al-Hadist, hasil-hasil penelitian yang berkaitan dengan jumlah besarnya produk pembiayaan pada perbankan syariah, hasil-hasil analisa ahli hukum terhadap peraturan yang berkaitan dengan perbankan syariah, artikel, buku, jurnal-jurnal, dan koran yang terkait erat dengan permasalahan yang akan menjadi pokok bahasan dalam penulisan ini.

Teknik pengumpulan data pada penelitian ini menggunakan beberapa teknik pengumpulan data. Untuk data primer dilakukan dengan menggunakan: (a) wawancara, yaitu percakapan dengan maksud tertentu yang dilakukan oleh dua pihak, yaitu pewawancara (interviewer) dan yang diwawancarai (interviewee), ${ }^{8}$ dengan memakai pedoman wawancara yang telah dipersiapkan sebelumnya. Manfaat wawancara adalah dapat memperoleh data sebanyak mungkin sehingga dapat dipahami budaya yang berkembang baik melalui bahasa maupun respon dari pihak yang diwawancarai, dan dapat melakukan klarifikasi atas hal-hal yang tidak diketahui, (b) Dokumentasi. Teknik dokumentasi digunakan untuk mencari data melalui sumber tertulis, seperti arsip, catatan, dokumen resmi, dan sebagainya, ${ }^{9}$ antara lain dari media cetak dan media elektronik mengenai pemberian pembiayaan oleh Lembaga Keuangan Syari'ah kepada usaha mikro, kecil dan menengah.

Teknik pengumpulan data sekunder pada penelitian ini diperoleh dengan studi kepustakaan yaitu teknik pengumpulan data dari Pusat Dokumentasi dan Informasi Hukum (PDIH) Fakultas Hukum Universitas Brawijaya, Perpustakaan Pusat Universitas Brawijaya, Perpustakaan Kota Malang, dan Internet.

Teknik pengolahan dan analisis data dilakukan dengan menggunakan teknik analisa deskriptif (description analysis). Hal ini berkaitan dengan upaya penulis mencermati, menganalisis, mendeskripsikan secara mendalam dan

\footnotetext{
${ }^{8}$ Burhan Ash-shofa, Metode Penelitian Hukum, (Jakarata: Rineka Cipta, 1998), h. 61.

${ }^{9}$ Suharsimi Arikunto, Prosedur Penelitian: Suatu pendekatan Praktek, (Jakarta: Rineka Cipta, 2002), h. 206.
} 
komprehensif data yang telah diperoleh melalui dokumentasi permasalahan, wawancara dan studi kasus penerapan pemberian pembiayaan dengan prinsip bagi hasil pada usaha mikro, kecil dan menengah (UMKM), hambatannya, serta solusi dalam mengatasi hambatan tersebut.

\section{HASIL DAN PEMBAHASAN}

Lembaga keuangan (financial institutions) adalah suatu perusahaan yang usahanya bergerak di bidang jasa keuangan. ${ }^{10}$ Ini berarti bahwa kegiatan yang dilakukan oleh lembaga ini akan selalu berkaitan dengan bidang keuangan, berupa penghimpunan dana, menyalurkan, dan/ atau jasa-jasa keuangan lainnya. Lembaga ini memiliki fungsi sangat penting, terutama sebagai lembaga intermediasi diantara para pemilik modal dengan pihak lain yang membutuhkannya. Selain lembaga keuangan yang telah ada, maka dalam perkembangannya hadir pula lembaga keuangan yang dalam menjalankan usahanya berdasarnya prinsip syariah, disebut sebagai Lembaga Keuangan Syari'ah. Kehadiran lembaga keuangan inilah yang memfasilitasi arus peredaran uang, sehingga uang dari masyarakat dapat dikumpulkan melalui berbagai bentuk produk penghimpunan dana sebelum disalurkan kembali kepada pihak yang membutuhkan dalam bentuk pembiayaan, baik yang bersifat sosial maupun bisnis.

Lembaga Keuangan Syari' ah pada penelitian ini difokuskan pada perbankan syariah dan Baitul Maal wat Tamwil (BMT). Menurut Ensiklopedi Islam, Bank Islam atau Bank Syari'ah adalah lembaga keuangan yang usaha pokoknya memberikan kredit dan jasa-jasa dalam lalu lintas pembayaran serta peredaran uang yang pengoperasiannya sesuai dengan prinsipprinsip syari'ah. ${ }^{11}$ Berbeda dengan Baitul Maal wat Tamwil (BMT) yaitu suatu lembaga yang terdiri dari dua istilah, yaitu baitul maal dan baitul tamwil. ${ }^{12}$ Baitul maal lebih mengarah pada

\footnotetext{
${ }^{10}$ Kasmir, Bank dan Lembaga Keuangan Lainnya, (Jakarta: Rajawali Press, 1998), h. 2.

${ }^{11}$ Warkum Sumitro, Asas-asas Perbankan Islam dan Lembaga-lembaga yang terkait. (Jakarta : Raja Grafindo, 1996), h. 5.

${ }^{12}$ Nurul Huda dan Mohamad Heykal, Lembaga Keuangan Islam: Tinjauan Teoritis dan Praktis, (Jakarta: Kencana, 2010), h. 363.
}

usaha-usaha penghimpunan dan penyaluran dana yang non profit, seperti zakat, infaq dan shodaqoh. Adapun baitul tamwil sebagai usaha penghimpunan dan penyaluran dana komersial. Dahulu Baitul Maal wat Tamwil (BMT) merupakan salah satu unit usaha pada sebuah koperasi yang menginginkan salah satu unit usaha adalah jasa keuangan mikro dengan berprinsip syariah. Saat ini dengan hadirnya Undang-Undang Nomor 1 Tahun 2013 tentang Lembaga Keuangan Mikro, maka Baitul Maal wat Tamwil (BMT) dapat berdiri sendiri dengan badan hukum berbentuk koperasi.

Baitul Maal wat Tamwil (BMT) juga merupakan lembaga ekonomi rakyat kecil yang berupaya mengembangkan usaha-usaha produktif dan investasi dalam rangka meningkatkan kegiatan ekonomi pengusaha kecil dengan berdasarkan prinsip syari ah dan prinsip koperasi. ${ }^{13}$ Berbeda dengan bank yang jenis usahanya lebih luas sehingga segmentasi yang dilayani juga lebih besar.

Hadirnya perbankan syariah di Indonesia adalah dalam rangka mendukung perekonomian Indonesia. Ekonomi dalam Islam adalah ilmu yang mempelajari segala perilaku manusia dalam memenuhi kebutuhan hidupnya dengan tujuan memperoleh falah (kedamaian dan kesejahteraan dunia akhirat). ${ }^{14}$ Perilaku manusia disini berkaitan dengan landasanlandasan syariah sebagai rujukan berperilaku dan kecenderungan-kecenderungan dari fitrah manusia. Kedua hal tersebut berinteraksi dengan porsinya masing-masing sehingga terbentuk sebuah mekanisme ekonomi yang khas dengan dasar-dasar nilai Ilahiah. Akibatnya masalah ekonomi dalam Islam adalah masalah menjamin berputarnya harta diantara manusia agar dapat memaksimalkan fungsi hidupnya sebagai hamba Allah untuk mencapai falah di dunia dan di akhirat (hereafter). Hal ini berarti bahwa aktivitas ekonomi dalam Islam adalah aktivitas kolektif, bukan individual.

\footnotetext{
${ }^{13}$ Ahmad Hasan Ridwan, BMT $\mathcal{E}$ Bank Islam Instrumen Lembaga Keuangan Syariah, (Bandung: Pustaka Bani Quraisy, 2004), h. 5

${ }^{14}$ Ascarya, Akad E Produk Bank Syariah, (Jakarta: RajaGrafindo Persada, 2011), h. 7
} 
Pendirian bank syariah dengan prinsip bagi hasil sudah sejak lama dicita-citakan oleh umat Islam di Indonesia. Hal itu terungkap dalam keputusan Majelis Tarjih Muhammadiyah yang diadakan di Sidoarjo, Jawa Timur pada tahun 1968. Dalam poin nomor 4 diputuskan, Majelis Tarjih menyarankan kepada Pimpinan Pusat Muhammadiyah untuk mengusahakan terwujudnya konsepsi sistem perekonomian, khususnya lembaga perbankan yang sesuai dengan kaidah Islam. ${ }^{15}$

Kaidah Islam yang dimaksud di atas adalah adanya ketentuan hukum bahwa riba merupakan sesuatu yang telah diharamkan sehingga dilarang oleh agama. Keberadaan perbankan konvensional dengan sistem bunga merupakan bentuk riba, sehingga kemudian timbul pemikiran mendirikan bank syariah yang bertujuan untuk menjauhkan umat dari praktik riba dalam kegiatan usaha perbankan.

Pengharaman terhadap praktik riba di kalangan umat Islam sudah cukup jelas dan telah disepakati bersama di kalangan para ulama. Tidak terdapat perbedaan pendapat diantara mereka tentang haramnya riba, karena secara jelas terdapat nash di dalam al-Qur'an tentang bagaimana riba tidak boleh dilakukan dalam interaksi sosial di masyarakat. Riba mengandung unsur ketidakadilan, yang akan ditimbulkannya, karena salah satu pihak akan mengeksploitasi dan berlaku dzalim terhadap yang lainnya. ${ }^{16}$

Pelarangan riba telah diatur secara tegas di dalam al-Qur'an, yaitu Surat Al-Baqarah ayat 275, 276, dan 278. Sebagaimana telah diketahui bahwa kaidah hukum asal dalam syariah adalah ibadah dan muamalah. Ketika suatu transaksi baru muncul dan belum dikenal sebelumnya dalam hukum Islam, maka transaksi tersebut dianggap dapat diterima, kecuali terdapat implikasi dari dalil al-Qur'an dan Al-Hadist yang melarangnya, baik secara eksplisit maupun implisit. Jadi dalam bidang muamalah semua transaksi dibolehkan kecuali yang diharamkan.

\footnotetext{
${ }^{15}$ Suhrawardi K. Lubis, Hukum Ekonomi Islam, (Jakarta: Sinar Grafika, 2004), h. 47.

${ }^{16}$ Nadratuzzaman Hosen, Hasan Ali, Bakhrul Muchtasib, Menjawab Keraguan Umat Islam Terhadap Bank Syariah, Cet. 1, (Jakarta: Pusat Komunikasi Syariah, 2007), h. 3
}

Adanya pembedaan antara bank umum yang kemudian dikenal sebagai bank umum konvensional dengan bank syariah adalah pembedaan menurut kegiatan usahanya. Bank umum konvensional melaksanakan kegiatan usahanya secara konvensional, sedangkan bank syariah melaksanakan kegiatan usahanya dengan berdasarkan prinsip syariah. ${ }^{17}$ Pada bank konvensional sesuai dengan Undang-Undang Nomor 7 Tahun 1992 sebagaimana telah diubah dengan Undang-Undang Nomor 10 Tahun 1998 tentang Perbankan juga diperbolehkan untuk melakukan dual banking system, yaitu di samping melaksanakan kegiatan usaha secara konvensional juga diperbolehkan membentuk unit usaha syariah (UUS) yang dalam kegiatan usahanya berdasarkan prinsip syariah. Sebaliknya pada perbankan syariah terdapat larangan untuk melakukan kegiatan usaha secara konvensional.

Fungsi utama perbankan seperti menerima deposit, memberikan kredit atau pembiayaan berdasarkan prinsip syariah dan melakukan jasa transfer keuangan, dan lain-lain merupakan bagian yang tidak terpisahkan dari kehidupan umat Islam. ${ }^{18}$ Di dalam sejarah perekonomian umat Islam, pembiayaan yang dilakukan dengan akad yang sesuai syariah telah menjadi bagian dari tradisi umat Islam sejak zaman Rasulullah SAW. Bentuk akad seperti menerima titipan, meminjamkan uang dan pembiayaan usaha, serta melakukan berbagai akad terkait dengan jasa keuangan sudah merupakan bagian dari kehidupan muamalat saat itu.

Kegiatan penyaluran dana dalam bentuk pembiayaan dengan prinsip bagi hasilmerupakan perwujudan nilai dasar dari sistem hukum ekonomi Islam, yaitu kerja sama antara pemilik modal atau uang dengan pengusaha yang mempunyai keahlian, keterampilan atau tenaga dalam melaksanakan unit-unit ekonomi atau usaha. ${ }^{19}$ Prinsip bagi hasil secara umum dapat dilakukan dalam 4 (empat) akad,

\footnotetext{
${ }^{17}$ Djoni S. Gazali dan Rachmadi Usman, Hukum Perbankan, (Jakarta: Sinar Grafika, 2012), h. 153-155

${ }^{18}$ Adiwarman A. Karim, Bank Islam: Analisa Fikih dan Keuangan, (Jakarta: RajaGrafindo Persada, 2004), h. 18.

${ }^{19}$ A.M. Saefuddin, Studi Sistem Ekonomi Islam, (Jakarta: Media Dakwah, 1984), h. 19-105
} 
yaitu musyarakah, mudharabah, muzara'ah, dan musaqah. Pada praktiknya, perbankan syariah lebih banyak memakai akad musyarakah dan mudharabah. ${ }^{20}$

Filosofi dan sifat dari pembiayaan dengan prinsip bagi hasiladalah untuk menyatukan capital dengan labour (skill dan enterpreneurship) yang selama ini terpisah dalam sistem konvensional karena memang sistem tersebut diciptakan untuk menunjang mereka yang memiliki capital (modal).

Bentuk pembiayaan yang diharapkan mampu memberikan pemerataan kesejahteraan masyarakat adalah pembiayaan mudharabah dan musyarakah dengan prinsip bagi hasil (profit sharing). ${ }^{21}$ Mudharabah merupakan skema yang paling mendasar dalam memobilisasi sumber-sumber dana yaitu penggabungan antara pemilik dana dan pihak lain yang memiliki keterampilan menjalankan usaha. ${ }^{22}$ Pembiayaan mudharabah memiliki filosofi yaitu menyatukan modal (capital) dengan tenaga kerja (skill dan entrepreneurship). Hal inilah yang tidak ditemukan pada sistem perbankan konvensional. ${ }^{23}$ Pada pembiayaan mudharabah bank bertindak sebagai shahibul maal yang menyediakan dana secara penuh dan nasabah bertindak sebagai mudharib yang mengelola dana dalam kegiatan usaha, oleh karenanya maka pembiayaan mudharabah ini sangat bermanfaat untuk memenuhi kebutuhan permodalan usaha nasabah. Musyarakah adalah akad kerjasama atau percampuran antara dua pihak atau lebih untuk melakukan usaha tertentu yang halal dan produktif dengan kesepakatan bahwa keuntungan akan dibagi sesuai dengan nisbah yang disepakati dan risiko akan ditanggung sesuai porsi kerjasama. ${ }^{24}$ Pada pembiayaan musyarakah bank sebagai shahibul maal memenuhi sebagian modal suatu

\footnotetext{
${ }^{20}$ Muhammad Syafi'i Antonio, Bank Syariah: dari Teori ke Praktik, (Jakarta: Gema Insani Press, 2001), h. 85.

${ }^{21}$ BurhanuddinS, Hukum Bisnis Syariah, (Yogyakarta: UII Press, 2011), h. 125.

${ }^{22}$ Hirsanuddin, Hukum Perbankan Syariah di Indonesia, (Yogyakarta: Genta Press, 2008), h. 121.

${ }^{23}$ Suhrawardi K. Lubis dan Farid Wajdi, Hukum Ekonomi Islam, (Jakarta: Sinar Grafika, 2012), h. 57

${ }^{24}$ Sunarto Zulkifli, Panduan Praktis Transaksi Perbankan Syariah, (Jakarta: Zikrul Hakim, 2004), h. 51.
}

usaha mudharib berdasarkan persetujuan atau kesepakatan. Bank dan mudharib masingmasing bertindak sebagi mitra usaha, mudharib bertindak sebagai pengelola usaha dan bank sebagai mitra usaha dapat ikut serta dalam pengelolaan usaha sesuai dengan tugas dan kewenangan yang disepakati.

Dikeluarkannya Undang-Undang Nomor 7 tahun 1992 sebagaimana diubah dengan Undang-Undang Nomor 10 Tahun 1998 tentang Perbankan, Undang-Undang Nomor 21 Tahun 2008 tentang Perbankan Syariah, serta adanya Undang-Undang Nomor 1 Tahun 2013 tentang Lembaga Keuangan Mikro, membuka peluang dibukanya lembaga keuangan yang dioperasikan berdasarkan pada prinsipprinsip syari'ah, diantaranya perbankan syari'ah dan Baitul Maal Wattamwil (BMT). Dalam kegiatan operasionalnya, baik bank syariah maupun Baitul Maal Wattamwil (BMT) memiliki kebijaksanaan yang berbeda-beda baik dalam hal penghimpunan dana maupun penyaluran dana.

Penyaluran dana oleh Lembaga Keuangan Syari'ah dikenal dengan sebutan pembiayaan, berbeda dengan penyaluran dana oleh lembaga keuangan konvensional yang dikenal dengan sebutan kredit. Pada Lembaga Keuangan Syari'ah, ketentuan pembiayaan juga memiliki kebijaksanaan yang berbeda-beda, bervariasi dan tergantung pada kebutuhan di masyarakat.

Penelitian menunjukkan bahwa tidak semua Lembaga Keuangan Syari'ah di Kota Malang menerapkan pembiayaan dengan prinsip bagi hasil. Beberapa Lembaga Keuangan Syari' ah juga menggunakan prinsip jual beli yaitu murabahah, padahal sebagaimana diketahui bahwa prinsip murabahah menerapkan margin keuntungan yang berarti bahwa bank meyakini bahwa usaha tersebut akan mendapatkan keuntungan juga. Hal ini berbeda dengan prinsip bagi hasil yang memperhitungkan adanya kemungkinan terjadinya impas atau tidak didapatnya keuntungan, bahkan terjadi kerugian. Pada prinsip bagi hasil, diyakini bahwa mudharib tidak mungkin berkeinginan untuk mendapatkan kerugian, baik kerugian tenaga, 
waktu, serta kesempatan untuk memperbesar usahanya sehingga keuntungan yang didapat juga semakin besar.

Penelitianjuga menunjukkan bahwa walaupun bank sebagai salah satu lembaga keuangan telah menerapkan prinsip bagi hasil, namun dengan diterapkannya akad musyarakah dalam memberikan pembiayaan kepada usaha mikro, kecil dan menengah(UMKM), maka berarti bank hanya bersifat memberikan tambahan modal saja atas suatu usaha yang sudah berjalan, belum memberikan bantuan modal kepada nasabah yang memiliki kemampuan dan keterampilan namun tidak memiliki modal untuk memulai usaha. Sebagaimana diketahui bahwa usaha mikro kecil dan menengah (UMKM) di Malang bukan hanya yang bergerak di bidang industri yang membutuhkan bantuan modal, namun dengan besarnya jumlah penduduk maka yang berpotensi untuk diberdayakan juga adalah para pedagang kaki lima, misalnya saja penjual makanan, minuman, kebutuhan pokok, dan lain sebagainya.

Pemberian pembiayaan dengan prinsip bagi hasil kepada usaha mikro, kecil dan menengah (UMKM) menggunakan prosedur umum pembiayaan, mulai dari pengajuan, analisis kelayakan, pembuatan akad (perjanjian), dan pengawasan. Pengajuan disertai dengan penyertaan dokumen-dokumen yang diperlukan, terlebih karena pemberian pembiayaan adalah kepada suatu badan hukum. Selanjutnya dilakukan analisis kelayakan usaha, dalam hal ini bank akan menerapkan prinsip $5^{\prime} \mathrm{Cs}$ yaitu: Character (penilaian watak/kepribadian), Chapacity (penilaian kemampuan), Capital (penilaian modal), Condition ofeconomy (penilaian terhadap keadaan pasar), dan Collateral (penilaian jaminan). Selain prinsip 5'Cs, terdapat juga prinsip lain yang digunakan dalam melakukan analisa kelayakan, yaitu: Party, Purpose, Payment, Profitability, Protection. Ada juga prinsip 3R, yaitu: Returns, Repayment, serta Risk Bearing Ability.

Bentuk ansisipasi agar tidak terjadi permasalahan di kemudian hari (macet), maka bank meminta calon debitur menyediakan jaminan berupa agunan yang nilainya minimal sebesar jumlah kredit atau pembiayaan yang diberikan kepadanya. Jaminan ini biasanya berupa sertifikat hak kepemilikan tanah dan bangunan serta hak kepemilikan kendaraan bermotor.

Setelah melakukan analisis menggunakan prinsip 5'Cs diatas dan diputuskan bahwa nasabah tersebut layak untuk diberikan pembiayaan, maka bank akan membuat suatu akad (perjanjian). Akad (perjanjian) pembiayaan harus dibuat tertulis dengan memperhatikan rukun dan syarat-syarat sesuai dengan hukum Islam.

Prosedur umum pengajuan pembiayaan mulai dari pengajuan permohonan hingga pengawasan oleh bank, merupakan upaya bagi bank dalam menghindari risiko kredit macet. Sebagaimana dikatakan oleh Sutan Remy Sjahdeini bahwa setiap kredit atau pembiayaan berdasarkan prinsip syariah yang akan disalurkan pada nasabah tidak akan lepas dari tahapan dari proses pemberian kredit atau pembiayaan berdasarkan prinsip syariah, tahapan tersebut antara lain: (a) Tahap sebelum pemberian kredit atau pembiayaan berdasarkan prinsip syariah diputuskan oleh bank, yaitu tahap bank mempertimbangkan permohonan kredit atau pembiayaan berdasarkan prinsip syariah calon debitur, ini disebut tahap analisa kredit. (b) Tahap setelah kredit atau pembiayaan berdasarkan prinsip syariah diputuskan pemberiannya oleh bank dan kemudian penuangan keputusan ke dalam perjanjian kredit atau pembiayaan berdasarkan prinsip syariah serta dilaksanakannya pengikatan agunan untuk kredit atau pembiayaan berdasarkan prinsip syariah yang diberikan ini. Tahap ini disebut tahap dokumentasi kredit. (c) Tahap setelah perjanjian kredit atau pembiayaan berdasarkan prinsip syariah ditandatangani oleh kedua belah pihak dan dokumentasi pengikatan agunan kredit atau pembiayaan berdasarkan prinsip syariah telah selesai dibuat serta selama kredit atau pembiayaan berdasarkan prinsip syariah itu digunakan oleh nasabah debitur sampai jangka waktu kredit atau pembiayaan berdasarkan prinsip 
syariah belum berakhir. Tahap ini disebut tahap pengawasan dan pengamanan kredit atau pembiayaan berdasarkan prinsip syariah. (d) Tahap setelah kredit atau pembiayaan berdasarkan prinsip syariah bermasalah yaitu tahapan penyelamatan dan penagihan kredit atau pembiayaan berdasarkan prinsip syariah. ${ }^{25}$

Tahap pertama sampai tahap ketiga adalah tahap preventif atau tahap pencegahan bagi bank agar kredit atau pembiayaan berdasarkan prinsip syariah tidakjadi bermasalah, sedangkan tahap keempat adalah tahap represif setelah kredit atau pembiayaan berdasarkan prinsip syariah bermasalah.

Kecilnya porsi pembiayaan oleh Lembaga Keuangan Syari'ah dengan prinsip bagi hasil karena dihadapkan pada beberapa faktor. Instrumen yang digunakan dalam menemukan faktor penghambat tersebut adalah instrumen penilaian efektifitas hukum, yaitu: (a) hukum atau peraturan itu sendiri (substansi hukum), (b) mentalitas petugas yang menegakkan (struktur hukum), (c) fasilitas yang diharapkan untuk mendukung pelaksanaan hukum, (d) kesadaran hukum dan budaya masyarakat (budaya hukum). Melalui instrumen penilaian diatas, maka dapat diketahui faktor-faktor penghambat tersebut tersebut antara lain: Pertama, hukum atau peraturan itu sendiri (substansi hukum), antara lain pelaksanaan prinsip kehati-hatian (prudential principle) yang diberlakukan oleh dunia perbankan. Prinsip ini membuat bank konvensional maupun bank syariah melakukan kegiatan usaha menghimpun dana dari masyarakat dan menyalurkannya kembali kepada masyarakat bertindak secara hati-hati, cermat, teliti dan bijaksana guna meminimalisir kemungkinan risiko yang kesemuanya adalah dalam rangka memberikan perlindungan terhadap dana masyarakat yang dipercayakan kepada lembaga perbankan, terlebih pada produk pembiayaan dengan prinsip bagi hasil yang bisa digunakan oleh usaha mikro, kecil dan menengah (UMKM)

\footnotetext{
${ }^{25}$ Sutan Remy Sjahdeini, Makalah "Pencegahan dan Penanggulangan Kredit Bermasalah", Magister Hukum Universitas Surabaya, 1995, h. 81.
}

dalam mengatasi permasalahan modal bagi usahanya, memiliki risiko yang tinggi, yaitu diantaranya side streaming, yaitu nasabah menggunakan dana tersebut bukan seperti dalam kontrak, lalai dan kesalahan yang disengaja, penyembunyian keuntungan oleh nasabah bila nasabahnya tidak jujur.

Wujud kehati-hatian perbankan dikenal dengan prinsip 5'Cs. Analisis diatas dipergunakan oleh bank konvensional maupun bank syari'ah sebelum kredit dikucurkan, sehingga memberikan keyakinan kepada bank bahwa proyek yang akan dibiayai dengan kredit bank cukup layak (feasible) ${ }^{26}$

Prinsip kehati-hatian menimbulkan dua kondisi yaitu, pertama, collateral oriented (berorientasi pada agunan). Prinsip ini sebenarnya merupakan prinsip yang ada pada Undang-Undang Nomor 14 tahun 1967 tentang Pokok-Pokok Perbankan yang saat ini sudah tidak berlaku lagi. Berdasarkan ketentuan pasal tersebut, pemberian kredit hanya akan dilakukan oleh bank bila sebelumnya nasabah debitur menyediakan jaminan. Bank dilarang untuk memberikan kredit jika tidak disertai dengan jaminan karena jaminan merupakan syarat utama agar pemberian kredit dicairkan. Jaminan yang dimaksud disini adalah berupa jaminan kebendaan, yang dinamakan dengan agunan.

Undang-Undang Nomor 7 Tahun 1992 sebagaimana diubah dengan Undang-Undang Nomor 10 tahun 2008 tentang Perbankan, tidak lagi menggunakan prinsip tersebut, bahkan pada dasarnya ingin mengubah orientasi bank dan ingin memberikan kelonggaran kepada nasabah dalam hubungannya dengan kesulitan nasabah untuk dapat menyerahkan agunan. Bagi usaha mikro kecil khususnya, kewajiban adanya jaminan tersebut tentu akan sangat memberatkan, hal tersebut dapat dipahami mengingat usaha mikro kecil berdiri dengan modal yang tidak besar dan terbatas, bahkan hanya berbekal keahlian dan keterampilan serta tekad yang besar karena melihat adanya peluang untuk berkembang.

${ }^{26}$ Lukman Dendawijaya, Manajemen Perbankan, (Bogor: Ghalia Indonesia, 2003), h. 91. 
Bila memperhatikan Undang-Undang Nomor 7 Tahun 1992 sebagaimana diubah dengan Undang-Undang Nomor 10 tahun 2008 tentang Perbankan maka terdapat dua istilah yang memiliki perbedaan arti, yaitu istilah jaminan dan agunan. Pasal 8 ayat 1 UndangUndang Nomor 7 Tahun 1992 sebagaimana diubah dengan Undang-Undang Nomor 10 tahun 2008 tentang Perbankan menyatakan:

“Dalam memberikan kredit atau pembiayaan berdasarkan prinsip syariah, bank umum wajib mempunyai keyakinan berdasarkan analisis yang mendalam atas itikad dan kemampuan serta kesanggupan nasabah debitur untuk melunasi utangnya atau mengembalikan pembiayaan dimaksud sesuai dengan yang diperjanjikan."

Penjelasan atas Pasal 8 ayat 1 UndangUndang Nomor 7 Tahun 1992 sebagaimana diubah dengan Undang-Undang Nomor 10 tahun 2008 tentang Perbankan menyatakan:

"Untuk mengurangi risiko tersebut, jaminan pemberian kredit atau pembiayaan berdasarkan prinsip syariah dalam arti keyakinan atas kemampuan dan kesanggupan nasabah debitur untuk melunasi kewajibannya sesuai dengan diperjanjikan merupakan faktor penting yang harus diperhatikan oleh bank. Untuk memperoleh keyakinan tersebut, sebelum memberikan kredit, bank harus melakukan penilaian yang saksama terhadap watak, kemampuan, modal, agunan dan prospek usaha dari nasabah debitur.

Mengingat bahwa agunan sebagai salah satu unsur pemberian kredit, maka apabila berdasarkan unsur-unsur lain telah diperoleh keyakinan, agunan dapat hanya berupa barang, proyek, atau hak tagih yang dibiayai dengan kredit yang bersangkutan"

Ketentuan Pasal 8 ayat 1 Undang-Undang Nomor 7 Tahun 1992 sebagaimana diubah dengan Undang-Undang Nomor 10 tahun 2008 tentang Perbankan, bila dihubungkan dengan penjelasannya menunjukkan bahwa makna kata jaminan tidak sama dengan makna kata agunan. Agunan hanyalah salah satu unsur dalam pemberian kredit, sedangkan jaminan berwujud keyakinan atas kemampuan dan kesanggupan nasabah debitur untuk melunasi kewajibannya sesuai dengan yang diperjanjikan, namun dalam praktiknya, yang dimaksud jaminan pemberian kredit atau pembiayaan berdasarkan prinsip syariah adalah agunan, dalam hal ini pada umumnya berwujud benda tertentu yang bernilai ekonomis guna dipakai sebagai pelunasan kredit atau pembiayaan berdasarkan prinsip syariah jika nasabah debitur wanprestasi.

Undang-Undang Nomor 7 Tahun 1992 sebagaimana diubah dengan Undang-Undang Nomor 10 tahun 2008 tentang Perbankan, pada dasarnya ingin mengubah orientasi bank dan ingin memberikan kelonggaran kepada nasabah dalam hubungannya dengan kesulitan nasabah untuk dapat menyerahkan agunan. Orientasi bank selama ini adalah mewajibkan atau menjadi keharusan tersedianya agunan atas kredit atau pembiayaan berdasarkan prinsip syariah. Padahal kewajiban adanya agunan tidak tercantum dalam UndangUndang Nomor 7 Tahun 1992 sebagaimana diubah dengan Undang-Undang Nomor 10 tahun 2008 tentang Perbankan,

Kedua, mentalitas petugas yang menegakkan (struktur hukum) yaitu membuka peluang untuk bank membuat suatu self regulatory banking, yang berisi tentang ketentuan intern bank dalam menjalankan usahanya, walaupun tetap tidak diperbolehkan menyalahi ketentuan yang telah ditetapkan Bank Indonesia. Adanya self regulatory banking tersebut tentu akan membuka peluang untuk bank dengan bebas membuat aturan sesuai dengan keinginannya sendiri tanpa memperhatikan bahwa ada pihak-pihak yang mungkin tidak memiliki kemampuan yang sama.

Adanya kemampuan yang tidak sama tersebut diatas misalnya saja dalam hal adanya jaminan. Jaminan di dalam hukum Islam dibagi menjadi dua, yaitu jaminan yang berupa orang (personal guaranty) dan jaminan yang berupa harta benda. Jaminan yang berupa orang (personal guaranty) dalam Islam disebut dengan kafalah, sedangkan jaminan yang berupa harta benda dalam Islam disebut dengan rahn. 
Keberadaan jaminan (agunan) bagi pembiayaan bagi hasil telah diakui oleh Majelis Ulama Indonesia. Untuk pembiayaan musyarakah diakui berdasarkan Fatwa Dewan Syariah Nasional No: 08/DSN-MUI/IV/2000 tentang Pembiayaan Musyarakah. Pada angka 3 dinyatakan bahwa pada prinsipnya dalam pembiayaan musyarakah tidak ada jaminan, namun untuk menghindari terjadinya penyimpangan, Lembaga Keuangan Syari'ah dapat meminta jaminan." Sedangkan untuk pembiayaan mudharabah diakui berdasarkan Fatwa Dewan Syariah Nasional No: 07/DSNMUI/IV/2000 tentang Pembiayaan Mudharabah (Qiradh). Pada angka 7 dinyatakan bahwa pada prinsipnya, dalam pembiayaan mudharabah tidak ada jaminan, namun agar mudharib tidak melakukan penyimpangan, Lembaga Keuangan Syari'ah dapat meminta jaminan dari mudharib atau pihak ketiga. Jaminan ini hanya dapat dicairkan apabila mudharib terbukti melakukan pelanggaran terhadap hal-hal yang telah disepakati bersama dalam akad.

Hadirnya Peraturan Bank Indonesia Nomor 14/22/PBI/2012 tentang Pemberian Kredit atau Pembiayaan Oleh Bank Umum dan Bantuan Teknis Dalam Rangka Pengembangan Usaha Mikro, Kecil dan Menengah, yang dalam pasal 2 menyebutkan bahwa bank umum wajib memberikan kredit atau pembiayaan kepada usaha mikro, kecil dan menengah (UMKM) dengan jumlah kredit atau pembiayaan ditetapkan paling rendah $20 \%$ (dua puluh persen) yang dihitung berdasarkan rasio kredit atau pembiayaan usaha mikro, kecil dan menengah (UMKM) terhadap total kredit atau pembiayaan, seharusnya akan mampu meningkatkan jumlah pembiayaan khususnya bagi usaha mikro, kecil dan menengah di Kota Malang. Terlebih di dalam Undang-Undang Nomor 20 Tahun 2008 tentang Usaha Mikro, Kecil dan Menengah juga menyebutkan bahwa Pemerintah menumbuhkan iklim usaha dengan menetapkan peraturan perundang-undangan dan kebijakan yang salah satunya meliputi aspek pendanaan guna membantu para pelaku usaha mikro, kecil dan menengah untuk mendapatkan pembiayaan dan jasa/produk keuangan lainnya yang disediakan oleh perbankan dan lembaga keuangan bukan bank, baik yang menggunakan sistem konvensional maupun syari' ah dengan jaminan yang disediakan pemerintah.

Ketiga, fasilitas yang diharapkan untuk mendukung pelaksanaan hukum, yaitu Sumber Daya Insani (SDI) juga menjadi permasalahan tersendiri bagi pihak bank. Terlebih sistem perbankan syariah di Indonesia masih belum lama dikenal, sehingga lembaga akademik dan pelatihan masih sangat terbatas. Hal ini menyebabkan tenaga terdidik dan berpengalaman di bidang perbankan syariah kurang memadai, padahal keberhasilan pengembangan bank syariah terutama dalam hal pengembangan usaha mikro, kecil dan menengah (UMKM) sangat ditentukan oleh kualitas manajemen dan tingkat pengetahuan serta keterampilan pengelola bank. Selain Sumber Daya Insani yang belum memadai, faktor lain yang menjadi kendala adalah dalam hal pengembangan jaringan kantor bank syariah. Hal tersebut diperlukan dalam rangka perluasan jangkauan pelayanan kepada masyarakat. Sebagaimana diketahui bahwa usaha mikro, kecil dan menengah (UMKM) merupakan unit usaha yang tersebar hingga ke pelosok daerah, bukan hanya berada di tengah kota. Kurangnya jumlah bank syariah hingga ke pelosok daerah sangat berbeda dengan jaringan bank konvensional yang jangkauannya sangat luas. Hal ini tentu berpengaruh terhadap kompetisi kualitas pelayanan dan inovasi produk perbankan syariah iitu sendiri. Dari hasil penelitian menunjukkan bahwa selain kredibilitas, maka kualitas pelayanan juga mempengaruhi pilihan masyarakat untuk bergabung pada suatu bank.

Keempat, kesadaran hukum dan budaya masyarakat (budaya hukum), yaitu bahwa usaha mikro, kecil dan menengah (UMKM) kurang menyadari pentingnya menjadi unit usaha yang bankable. Usaha yang bankable disini adalah usaha yang layak untuk dibiayai. Beberapa kriteria untuk menjadi usaha yang bankable antara lain usaha tersebut berbadan hukum, memiliki NPWP (Nomor Pokok Wajib 
Pajak), memiliki pencatatan keuangan yang baik (termasuk di dalamnya invoice, tagihan, kwitansi, serta semua kertas atau dokumen yang berhubungan dengan usaha), serta memiliki aset (bisa berupa mesin, kendaraan, tanah). Penelitian menemukan bahwa untuk menjadi usaha yang bankable, kesadaran tersebut masih sangat minim di masyarakat. Hal inilah yang kemudian membuat bank tidak secara langsung memberikan pembiayaan kepada usaha mikro, kecil dan menengah (UMKM), melainkan pemberian modal usaha tersebut secara tidak langsung baik dengan pola executing maupun pola chanelling kepada koperasi atau lembaga keuangan mikro syariah yang ada. Hal tersebut disebabkan karena bank tidak menginginkan risiko yang tinggi atas pembiayaan yang diberikannya. Selain itu faktor kejujuran juga menjadi penghambat. Pada dasarnya hanya mudharib (pengelola usaha) saja yang mengetahui secara pasti kondisi usahanya. Inilah yang kemudian menimbulkan suatu kondisi yang disebut dengan asymmetric information, yaitu kondisi dimana salah satu pihak menguasai informasi lebih baik dibandingkan dengan pihak lainnya, atau salah satu pihak tidak memiliki informasi yang sama dengan pihak lainnya. Bank sepenuhnya mempercayakan pengelolaan dananya kepada mudharib, termasuk mempercayakan laporan keuntungan ataupun laporan kerugian. Bila mudharib menjunjung tinggi nilai kejujuran, maka mudharib tidak melakukan manipulasi data keuangan. Kemungkinan terjadinya asymmetric information inilah yang kemudian menjadikan pembiayaan dengan prinsip bagi hasil yang seharusnya menjadi produk unggulan pada perbankan syariah saat ini hanya merupakan sebagian kecil saja dari seluruh pembiayaan yang ada. ${ }^{27}$

Faktor-faktor penghambat diatas sebenarnya dapat diatasi dengan mengupayakan beberapa hal, antara lain: (a) pertama, perbaikan peraturan perbankan yaitu perlu disesuaikan agar bank dapat tetap dalam kondisi kesehatan yang baik dengan menerapkan prinsip kehati-

${ }^{27}$ Adiwarman A. Karim, Ekonomi Islam, Suatu Kajian Kontemporer, (Jakarta: Gema Insani Press, 2001), h. 83 hatian, namun tetap memperhatikan kondisi nasabah yang tidak selalu sama. Misalnya dalam hal pembebanan jaminan yang terasa sangat memberatkan usaha mikro, kecil dan menengah (UMKM) yang terbatas terutama dalam hal asset.

Kedua, bagi usaha mikro, kecil dan menengah (UMKM) yang terkendala dengan jaminan, maka dapat menjadi anggota pada suatu koperasi primer. Perbankan syariah dapat melakukan pembiayaan dengan prinsip syariah dalam bentuk modal kerja dalam hal ini adalah pembiayaan dengan prinsip bagi hasil kepada koperasi primer untuk diteruskan kemudian pembiayaan tersebut diteruskan kepada anggotanya. ${ }^{28}$ Selain itu bank syariah dapat bekerja sama dengan lembaga keuangan mikro syariah yang segmentasi pembiayaannya ditujukan memang bagi usaha mikro.

Ketiga, peningkatan kualitas dan kuantitas Sumber Daya Insani perbankan syariah. Bagi perbankan syariah, maka pengembangan sumber daya insani tidak hanya memerlukan pengetahuan yang luas di bidang perbankan, memahami implementasi prinsip-prinsip syariah di dalam praktiknya, namun juga memiliki komitmen yang kuat untuk menerapkannya secara konsisten. Selain itu pengembangan jaringan kantor maupun lembaga keuangan mikro. Pengembangan jaringan kantor bank syariah sangat diperlukan dalam rangka perluasan jangkauan pelayanan kepada masyarakat. Sebagaimana pada perbankan konvensional yang memiliki jaringan kantor hingga ke pelosok daerah, maka perbankan syariah diharapkan memiliki jumlah jaringan yang luas sehingga akan meningkatkan efisiensi usaha serta meningkatkan kompetisi kearah peningkatan kualitas pelayanan dan mendorong inovasi produk dan jasa perbankan syariah.

Keempat, meningkatkan pemahaman masyarakat mengenai budaya kejujuran dan produk pembiayaan bank syariah. Perilaku atau perangai masyarakat yang dikhawatirkan oleh perbankan syariah tersebut di dalam sosiologi hukum telah disebutkan. Perilaku tidak jujur masyarakat dalam objek kajian sosiologi hukum disebut dengan behavior, yatu merupakan

\footnotetext{
${ }^{28}$ Ibid, h. 122.
} 
kenyataan hukum di masyarakat yang terkadang terjadi tidak sesuai dengan apa yang diharapkan. Dalam Islam, perilaku tersebut disebut dengan akhlak. Akhlak atau sistem perilaku dapat dipengaruhi oleh dua pendekatan, yaitu: ${ }^{29}$ (a) rangsangan, yaitu perilaku manusia terwujud karena adanya dorongan dari suatu keadaan. Pendekatan ini bisa dilakukan dengan cara terjun langsung di masyarakat, dengan memberikan pelatihan-pelatihan mengenai pembukuan atau manajemen keuangan yang baik, melakukan tanya jawab atas prospek usaha yang sedang dijalankan sehingga akan memberikan motivasi kepada para pengusaha tersebut untuk terus mengoptimalkan usaha. (b) Kognitif, yaitu penyampaian informasi yang didasari oleh dalil-dalil yang benar. Misalnya dalil al-Qur'an dan al-Hadist. Pendekatan ini dilakukan dengan menggelar diskusi ataupun seminar mengenai pentingnya mencari penghidupan yang lebih baik dengan usaha keras disertai kejujuran sebagaimana yang disebutkan di dalam al-qur' an dan al-Hadist. Solusi lain dalam mengatasi masalah terjadinya kondisi asymmetric information yang menyebabkan pihak bank tidak mengetahui dengan pasti kondisi usaha maupun kondisi keuangan dari mudharib adalah dengan mencantumkannya ke dalam salah satu klausul di dalam akad pembiayaan bank.

Perjanjian kredit bank dan perumusan klausul-klausul di dalamnya sangat tergantung dari kebutuhan calon debitur secara pribadi, dan bank harus dapat mengantisipasinya dengan cepat. ${ }^{30} \mathrm{Hal}$ ini berarti mudharib dan shahibul maal merupakan mitra dan tidak ada satu pihak yang dirugikan. Untuk itulah maka perjanjian kredit dibuat dengan sebelumnya dilakukan negosiasi diantara kedua belah pihak. Pihak bank dapat meminta dimasukkannya kondisi asymmetric information ke dalam salah satu klausul, yaitu yang berkaitan dengan penipuan data.

\footnotetext{
${ }^{29}$ Zainuddin Ali, Sosiologi Hukum, (Jakarta: Sinar Grafika:2008), h. 19-22.

${ }^{30}$ Johannes Ibrahim, Bank Sebagai Lembaga Intermediasi dalam Hukum Positif, (Bandung: utomo, 2004), h. 116.
}

\section{KESIMPULAN}

Pemberdayaan usaha mikro, kecil dan menengah(UMKM) melalui pembiayaan dengan prinsip bagi hasil oleh Lembaga Keuangan Syari' ah di kota Malang masih terbentur pada risiko yang harus dihadapi. Risiko tersebut berkaitan dengan kesulitan bank sebagai shahibul maal mendapatkan informasi yang akurat mengenai karakter nasabah pengelola (mudharib) dan mengenai usaha yang akan dibiayai pada saat menyeleksi mudharib dan usahanya tersebut. Oleh sebab itu maka untuk meminimalisir risiko yang ada bank menerapkan pola executing, yaitu melakukan pembiayaan mudharabah tidak secara langsung kepada usaha mikro, kecil dan menengah (UMKM) melainkan memberikan pembiayaan tersebut kepada koperasi primer serta Baitul Maal wat Tamwil (BMT).

Pemberdayaan usaha mikro kecil dan menengah (UMKM) oleh Lembaga Keuangan Syari'ah di Kota Malang terkendala oleh beberapa hal, misalnya berkaitan dengan prinsip kehati-hatian perbankan sebagaimana yang diamanatkan oleh undang-undang yaitu usaha yang tidak memiliki agunan maka dianggap tidak layak untuk mendapatkan pembiayaan. Kekhawatiran terjadinya asymmetric information yaitu pelaporan jumlah keuntungan yang tidak benar oleh mudharib juga menyebabkan bank sangat berhati-hati dalam memberikan pembiayaan dengan prinsip bagi hasil dalam jumlah yang banyak dan cenderung memberikan pembiayaan dengan prinsip yang lain yaitu jual beli karena dianggap lebih aman. Hal tersebut berkaitan juga dengan keterbatasan Sumber Daya Insani yang dimiliki oleh perbankan syariah. Usaha yang dijalankan oleh mudharib membutuhkan pengawasan oleh mereka yang berkompeten di bidangnya, dan pengawasan inilah yang bisa meminimalisir terjadinya asymmetric information antara shahibul maal dengan mudharib.

Terhadap kendala yang ada maka para pengusaha usaha mikro, kecil dan menengah (UMKM) yang tidak bankable dapat menjadi anggota pada suatu koperasi primer dengan 
salah satu pilihan pembiayaannya adalah pembiayaan dengan prinsip bagi hasil. Selain itu bank syariah bisa bekerja sama dengan lembaga keuangan mikro syari'ah yang segmentasi pembiayaannya memang diberikan kepada usaha mikro. Disamping itu bank harus memperluas jaringan sehingga masyarakat lebih memahami produk-produk yang disediakan termasuk pembiayaan untuk modal kerja, dengan tetap memberikan edukasi dan sosialisasi pentingnya menjadi unit usaha yang bankable. Bank syari'ah juga harus mengupayakan Sumber Daya Insani yang bukan hanya memiliki pengetahuan

\section{Daftar Pustaka}

Buku:

Adiwarman A. Karim. Ekonomi Islam, Suatu Kajian Kontemporer. Jakarta: Gema Insani Press, 2001.

Adiwarman A. Karim. Bank Islam: Analisa Fikih dan Keuangan. Jakarta: RajaGrafindo Persada, 2004.

Ahmad Hasan Ridwan. BMT \& Bank Islam Instrumen Lembaga Keuangan Syari'ah. Bandung: Pustaka Bani Quraisy, 2004.

A.M. Saefuddin. Studi Sistem Ekonomi Islam. Jakarta: Media Dakwah, 1984

Ascarya. Akad \& Produk Bank Syariah. Jakarta: RajaGrafindo Persada, 2011.

Burhan Ash-shofa. Metode Penelitian Hukum. Jakarata: Rineka Cipta, 1998.

BurhanuddinS. Hukum Bisnis Syariah. Yogyakarta: UII Press, 2011.

Djoni S. Gazali dan Rachmadi Usman. Hukum Perbankan. Jakarta: Sinar Grafika, 2012.

Hirsanuddin. Hukum Perbankan Syariah di Indonesia. Yogyakarta: Genta Press, 2008.

Johannes Ibrahim. Bank Sebagai Lembaga Intermediasi dalam Hukum Positif. Bandung: utomo, 2004.

Kasmir. Bank dan Lembaga Keuangan Lainnya. Jakarta: Rajawali Press, 1998.

Lukman Dendawijaya. Manajemen Perbankan. Bogor: Ghalia Indonesia, 2003.

Marzuki. Metodologi Riset. Yogyakarta: BPFE yang luas di bidang perbankan, memahami implementasi prinsip-prinsip syariah di dalam praktiknya, namun juga memiliki komitmen yang kuat untuk menerapkannya secara konsisten. Mengadakan workshop mengenai perbankan syariah, seminar atau sebagai pembicara pada suatu diskusi yang terkait dengan kebijakan perbankan syari' ah untuk berperan serta dalam pemberdayaan dan pengembangan usaha mikro, kecil dan menengah (UMKM) dengan memberikan sarana edukasi dan sosialisasi kepada masyarakat.

UII, 1986.

Muhammad Syafi'i Antonio. Bank Syariah: dari Teori ke Praktik. Jakarta: Gema Insani Press, 2001.

Nadratuzzaman Hosen, Hasan Ali, Bakhrul Muchtasib. Menjawab Keraguan Umat Islam Terhadap Bank Syariah. Jakarta: Pusat Komunikasi Syariah, 2007.

Nurul Huda dan Mohamad Heykal. Lembaga Keuangan Islam: Tinjauan Teoritis dan Praktis. Jakarta: Kencana, 2010.

Soerjono Soekanto dan Sri Mamudji. Penelitian Hukum Normatif: Suatu Tinjauan Singkat. Jakarta: Raja Grafindo Persada, 2003.

Suharsimi Arikunto. Prosedur Penelitian: Suatu Pendekatan Praktek. Jakarta: Rineka Cipta, 2002.

Suhrawardi K. Lubis. Hukum Ekonomi Islam. Jakarta: Sinar Grafika, 2004

Suhrawardi K. Lubis dan Farid Wajdi. Hukum Ekonomi Islam. Jakarta: Sinar Grafika, 2012.

Sunarto Zulkifli. Panduan Praktis Transaksi Perbankan Syariah. Jakarta:Zikrul Hakim, 2004.

Warkum Sumitro. Asas-asas Perbankan Islam dan Lembaga-lembaga yang terkait. Jakarta: Raja Grafindo, 1996.

Zainuddin Ali. Sosiologi Hukum. Jakarta: Sinar Grafika:2008.

Makalah dan Internet:

Bank Indonesia, “Buku Kajian Akademik Pemeringkat Kredit Bagi Usaha Mikro, 
Kecil dan Menengah di Indonesia", (Jakarta: Bank Indonesia, 2011). www.bi.go.id. Diakses tanggal 08 Februari 2013.

Artikel Suara Merdeka.com, “Bank Syariah dan Industri Kreatif", diakses tanggal 31 Desember 2012. Artikel Suara Merdeka. com, "Pertumbuhan Perbankan Syariah Belum Optimal", diakses tanggal 08 November 2012. Artikel Republica.co.id, "Pertumbuhan Perbankan Syariah Belum
Optimal", diakses tanggal 27 Oktober 2011. Artikel Kompas.com "Keterbatasan UKM Dalam Meraih Pembiayaan Bank Syariah", diakses tanggal 03 Januari 2010.

Sutan Remy Sjahdeini, Makalah "Pencegahan dan Penanggulangan Kredit Bermasalah", Magister Hukum Universitas Surabaya. 1995. 